\title{
DETERIORATION OF AGRICULTURAL YIELD OVER 35 YEARS: EVIDENCE FROM SIMULATED SEDIMENT EXPORT AND NUTRIENT DISCHARGE DATA WITHIN MICRO ENVIRONMENT
}

\author{
Mohd Sayeed Ul Hasan ${ }^{1, *}$, Subhajit Bandopadhyay ${ }^{2}$, Seemab Akhtar ${ }^{3}$, Prasenjit Saha ${ }^{4}$ \\ ${ }^{1}$ Centre for Oceans, Rivers, Atmosphere, and Land Science, Indian Institute of Technology (IIT) Kharagpur, Kharagpur, \\ India - sayeedgis@gmail.com \\ ${ }^{2}$ Department of Meteorology, Poznan University of Life Sciences, Poznan, Poland - subhajit.iirs@g,gmail.com \\ ${ }^{3}$ Indian Institute of Technology (IIT), Indian School of Mines (ISM), Dhanbad, India - akhtarau90@gmail.com \\ ${ }^{4}$ National Atlas and Thematic Mapping Oganisation (NATMO), Kolkata, India - sahaprasenjit815@gmail.com
}

\section{Commission III, WG III/10}

KEY WORDS: Agricultural yield, River discharge, Sedimentation process, Nutrient discharge, SWAT, Gandheshwari

\begin{abstract}
:
The present study is an evidence that depicts the degradation of agricultural yield in terms of soil nutrient $\left(\mathrm{NH}_{4}, \mathrm{NO}_{3}, \mathrm{NO}_{2}\right)$ deficit over 35 years (1979-2014) due to river sedimentation process within a small-scale basin. Literatures showed a significant decline in amount of nutrients from croplands in each year. In best of our knowledge, no such studies till date have examined small river basin environment to understand this inverse relationship between sedimentation process and soil nutrient loss using open source earth observation (EO) data and hydrological modelling at Indian context. SWAT model was applied to evaluate the basin hydrology and sedimentation process and associated soil nutrient conditions over time using historical flow and long-term meteorological data. Simulated sediment import and export significantly correlates $(p<0.00)$ with annual discharge values with the $\mathrm{R}^{2}$ of 0.93 and 0.99 respectively. However, over the time different nutrient contents of soil such as $\mathrm{NH}_{4}, \mathrm{NO}_{3}$ etc. decreased drastically. Output reviles that $\mathrm{NO}_{3}$ decreased from $32660 \mathrm{~kg} \mathrm{~N}$ to $5689 \mathrm{~kg} \mathrm{~N}$ within the observation period. Similarly, $\mathrm{NH}_{4}$, and $\mathrm{NO}_{2}$ also reduced with the $12020 \mathrm{~kg} \mathrm{~N}$ to $1577 \mathrm{~kg} \mathrm{~N}$ and $49.44 \mathrm{~kg} \mathrm{~N}$ to $6.85 \mathrm{~kg}$ $\mathrm{N}$ respectively. Total nitrogen and mineral phosphorus concentration also decreased over time. The Overall scenario showed that within 35 years, the increasing rate of sedimentation process through Gandheshwari river, adversely impact the agricultural yield concentration of the region. This study will help stakeholders, farmers to plan appropriate agricultural strategies at grass root level for small basin areas.
\end{abstract}

\section{INTRODUCTION}

Soil erosion and its associated nutrient loss by water is one of the most concerned land degradation issue in present days for Indian agricultural lands. In an era of climate change, soil erosion/sediment export is a serious problem that has threatened and encountered the Indian agricultural lands particularly located along river basins. These changes have caused in a massive mobilization of bioactive nutrients such as nitrogen and phosphorus (N and $\mathrm{P}$ ) on land which ultimately resulted in a soil nutrient lose for agricultural fields and its mainly impacted the agricultural yield (Seitzinger et al., 2005). Literature shows a significant decline in amounts of nutrients from the field, totalling $20.6 \mathrm{~kg} \mathrm{C}, 5.05 \mathrm{~kg} \mathrm{~N}, 0.05 \mathrm{~kg} \mathrm{P}$, and $9.94 \mathrm{~kg} \mathrm{~K}$ in each year from per hector of land. Such information on nutrient loss and its effects on agricultural yield at catchment scales is increasingly sought by catchment stakeholders and managers at present days. Though there were many studies have been conducted in this concern for developed nations (Merritt et al., 2003; Moore et al., 2010; Boesch et al., 2002; Seitzinger et al., 2005 ) but there are very limited experiments were done in Indian context where agriculture is the backbone of Indian economy. In best of our knowledge, no such studies till date have examined small river basin environment to understand this inverse relationship between sedimentation process and soil nutrient loss using open source earth observation (EO) data and hydrological modelling.

The aim of the present study was to show, how a simple physical based model can able to evaluate the hydrological scenario and soil erosion of a small river basin and its associated nutrient loss for surrounding agricultural fields over 35 years (1979-2014). The Soil and Water Assessment Tool (SWAT) model was applied to achieve the desired goal using historical flow and long-term meteorological data. In support of the model (LULC from Landsat 8 OLI, elevation model from SRTM 1 Arc-Second DEM, soil maps from FAO) data were included during the simulation period of 35 years. The investigation was conducted in a small basin of river Gandheshwari of Bankura district of West-Bengal state in India. Agriculture is the main source of economy in this region. Small Gandheshwari river basin is highly concentrated with agricultural fields where most of the fields are characterized with multi-crop facilities. But over time, the significant reduction of agricultural productivity in this region were noticeable, evident by local farmers perspective. With this curiosity, present

\footnotetext{
* Corresponding author: sayeedgis@gmail.com
} 
study was motivated and further examination was

\section{STUDY AREA}

Gandheshwari river basin is located in the Bankura district of West-Bengal state of India, having the extent latitude from $23.22^{\circ} \mathrm{N}$ to $23.51^{\circ} \mathrm{N}$ and longitude from $86.92^{\circ} \mathrm{E}$ to $87.05^{\circ} \mathrm{E}$ covering an area of $408.28 \mathrm{Km}^{2}$ (approx.). The study area comprises of four blocks namely Bankura, Saltora, Chatna and Gangajal Ghati. Gandheswari river flows from the Shusunia hill from north to south and meet Dwarkeshwar river at Bhutsahar. The basin area is mostly covered by the undulating surface but eastern part (Bankura town) is relatively flatter. The study area comes under the Chota Nagpur plateau and having wide range of morphometric variation over the terrain (Hasan et al. 2017). The water balance component of the catchment mainly influenced by climate as well as physical characteristics such as morphology, land use, slope and soil (Venkatesh et al. 2018). Extremity of climate is very prominent here, maximum temperature goes up to $42^{\circ} \mathrm{c}$ and minimum down to $6^{\circ} \mathrm{c}$ (Bandopadhyay S., 2016). Rainfall of this area varies between the $1055 \mathrm{~mm}$ to $1070.3 \mathrm{~mm}$ ( $\mathrm{Pal} \&$ debnath,2012). Almost $80 \%$ rainfall caused due to monsoon during June to September. The greatest measure of precipitation got amid the monsoon season from June to September around $80.73 \%$ (Hasan et al., 2018). The region experienced with extreme flooding during monsoon which is also impacted the surrounding agricultural fields and its productivity.

The geographic location of the study area shown in figure 1.

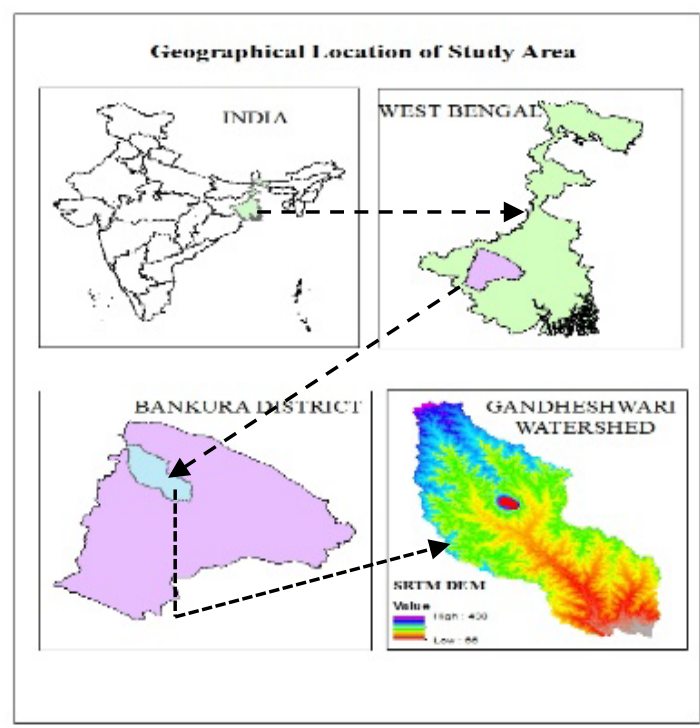

Figure 1. Location of the study area. The SRTM DEM of the Gandheshwari watershed was obtained from SRTM 1 Arc-Second DEM

\section{DATA AND METHODS}

The SWAT model have the capability to simulate the amount of nutrient and dynamic motion of water through conducted to find the actual scientific reasons behind it.

the catchment (Serur et al., 2016). A majority of researcher around the globe have identified that SWAT as the most promising and statistically efficient model. (Neitsch et al. 2005). SWAT have the ability to predict the environmental impact of land use, land management practices.

A combination of image processing and model simulation have been carried out in this study. Freely available Landsat 8 OLI, SRTM DEM and meteorological datasets have been used in this study. Satellite data were pre-processed in ERDAS and further ArcGIS have been used for working to input the data into ArcSWAT. The application of ArcSWAT plugin is basically for the developing countries where the availability of gauge stations are not available. The used datasets along with the flowchart of methodology given below (see figure 2).

Figure 2. Flowchart of methodology

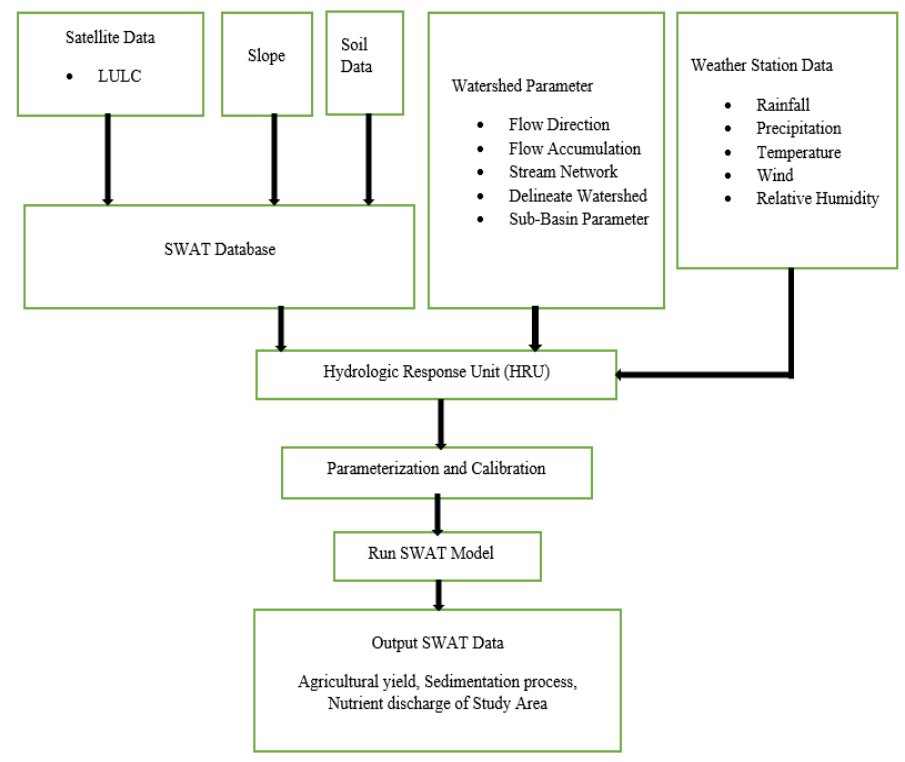

1. Digital Elevation Model (DEM): The Shuttle Radar Topographic Mission (SRTM) DEM of having resolution of $30 \mathrm{~m}$ used for delineating watershed and stream characteristics of the river. DEM is further use for the preparation of slope map which gives an idea about the flow gradient of the water from Shusunia hill towards the outlet of the Gandheshwari watershed. The slope data are reclassified into three classes. The mean sea elevation ranges from $66 \mathrm{~m}$ to maximum height of $438 \mathrm{~m}$ at the top of Shusunia hill.

2. Land Use Land Cover Map: Landsat 8 satellite data of the year 2014 is used for making the land use/ land cover using unsupervised classification. The land use is classified into five classes namely urban area $\left(8.98 \mathrm{Km}^{2}\right)$, water bodies $\left(11.60 \mathrm{Km}^{2}\right)$, barren 
land $\left(14.47 \mathrm{Km}^{2}\right)$, forest $\left(230.20 \mathrm{Km}^{2}\right)$ and agricultural land $\left(142.99 \mathrm{Km}^{2}\right)$.

3. Soil Map: The most important step in the SWAT is preparation of soil data set which plays a crucial role in the environmental parameters of any region. The soil map of the study area produced from the Food and Agriculture Organization (FAO) of the United Nations. The soil found in this area is luvisolic of having characteristics ferric luvisolic (Lf32-1b-3788).

4. Climate Data: The SWAT modelling generally required the climate input parameters like precipitation, solar radiation, relative humidity, wind speed and maximum-minimum temperature to run the Hydrological Response Unit (HRU). Before running up of the model all input data are rectified as per the SWAT format for the smooth functioning of the model.

Detailed methodology for this study is given in figure 2 .

\section{RESULTS}

The SWAT model divided the watershed into 7 subwatersheds and 28 HRUs for easy and accurate modelling.

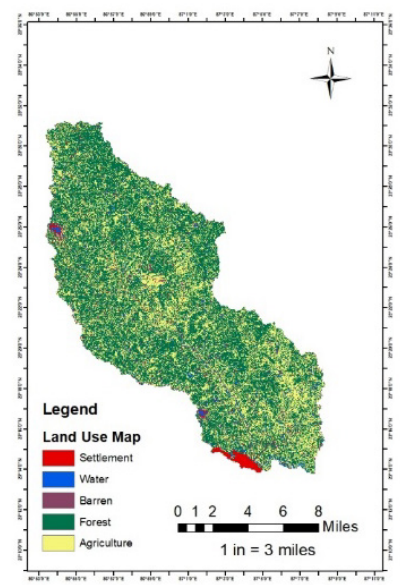

Figure 3. Land use map of the study area

\subsection{Hydrological scenario}

It was estimated from the model that the average annual precipitation of the basin is $1869.4 \mathrm{~mm}$, surface runoff (SUR Q) is $501.94 \mathrm{~mm}$, lateral discharge is $7.87 \mathrm{~mm}$, and groundwater discharge for shallow and deep aquifers is 637.27 and $35.24 \mathrm{~mm}$, respectively. The average value for total aquifer recharge is $716.12 \mathrm{~mm}$, the total water yield of the basin is $1182.65 \mathrm{~mm}$, and evapotranspiration is $637 \mathrm{~mm}$. A pictorial representation of the SWAT output regarding runoff and evapotranspiration is shown in figure 4. The average monthly values of all the hydrological parameters of the basin - that is, rainfall, snowfall, surface runoff, lateral runoff, water yield, and evapotranspiration-are given in appendix 1. It was also estimated that there are an average of 62.74 annual water-stress days and 3.88 temperature-stress days.

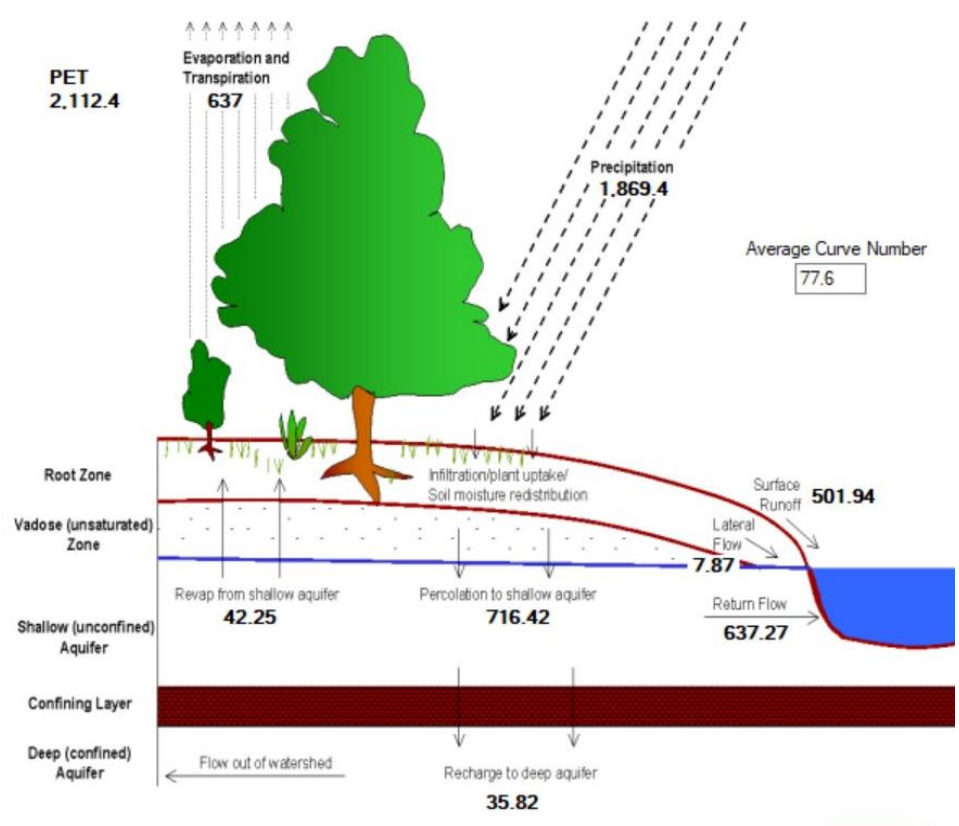

Figure 4. Hydrological scenario of Gandheshwari basin (All units are in $\mathrm{mm}$ ).

\subsection{Land use scenario}

The derived land use map of the study area showed that most of the land were occupied by forests and agricultural lands followed by barren land, small water bodies and settlement which is located at the south of the basin. The land use map of the basin shown in figure 4 .

\subsection{River discharge and sedimentation process}

No such big change has been observed in last 35 years in river discharge. Though there were fluctuations, but the overall trend in river discharge were quite stable over the examined period. The detailed trend shown in figure 5 .

River discharge (cubic meters per second)

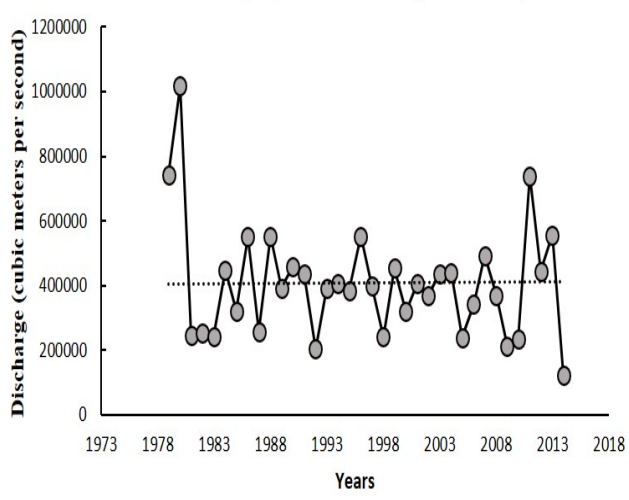

Figure 5. River discharge trend over 35 years 
SWAT model outcome showed a significant relationship $(\mathrm{p}<0.00)$ in between river discharge and in sedimentation process of the study area. 35 years of discharge data and sediment import and export data showed a good agreement with the $\mathrm{R}^{2}$ of 0.93 and 0.99 respectively. It denotes that the discharge of river Gandheshwari of 35 years have a significant influence on regional sedimentation process. The relationship between river discharge and sediment import and export was shown in figure 6 .

\subsection{Soil nutrient deficit}

Model derived outcome showed that over the time different nutrient contents of soil such as $\mathrm{NH}_{4}, \mathrm{NO}_{3} \mathrm{NO}_{2}$ decreased drastically. Output reviles that $\mathrm{NO}_{3}$ decreased from $32660 \mathrm{~kg}$ $\mathrm{N}$ to $5689 \mathrm{~kg} \mathrm{~N}$ within the observation period. Similarly, $\mathrm{NH}_{4}$, and $\mathrm{NO}_{2}$ also reduced with the $12020 \mathrm{~kg} \mathrm{~N}$ to $1577 \mathrm{~kg}$ $\mathrm{N}$ and $49.44 \mathrm{~kg} \mathrm{~N}$ to $6.85 \mathrm{~kg} \mathrm{~N}$ respectively. Figure 7 shows that during the observed period except $\mathrm{NO}_{3}$,export rate of other soil nutrients such as $\mathrm{NH}_{4}, \mathrm{NO}_{2}$ were high in comparison to soil nutrients import to the basin area.

Figure 7 showed that the rate of import and export for $\mathrm{NO}_{3}$ was quite similar although over 35 years the overall concentration of $\mathrm{NO}_{3}$ decreased drastically. Again the export rate of $\mathrm{NH}_{4}, \mathrm{NO}_{2}$ was quite high rather than the import rate in every year and overall concentration of these two nutrients were decreased in 35 years.

No,

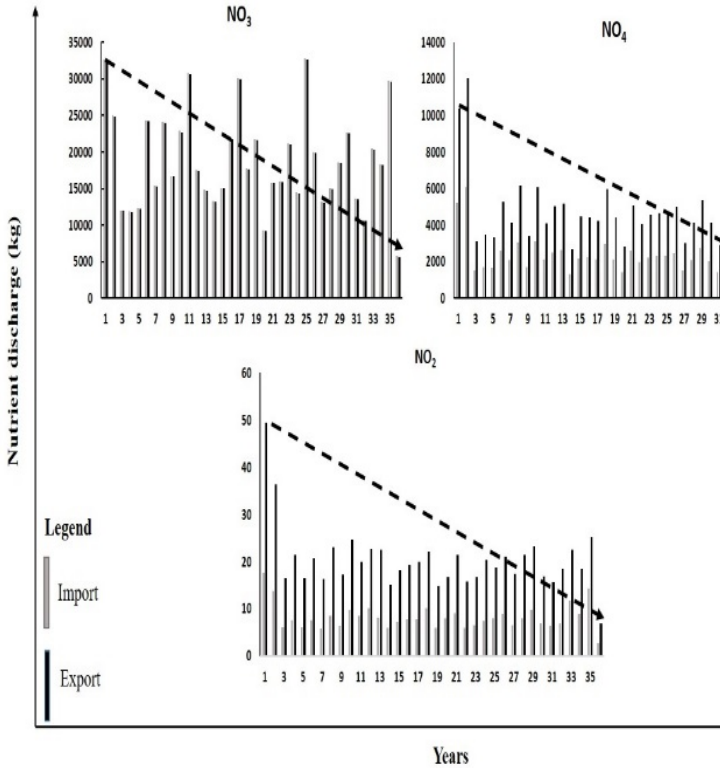

Figure 7. Discharge of soil nutrients $\left(\mathrm{NO}_{3}, \mathrm{NH}_{4}, \mathrm{NO}_{2}\right)$ over observed period.

Model derived outcomes were also showed that the overall concentration of nitrogen $(\mathrm{N})$ and phosphorus $(\mathrm{P})$ were decreased over time. Total $\mathrm{N}$ concentration were decreased from $1017000 \mathrm{~kg}$ to $123700 \mathrm{~kg}$ whereas overall $\mathrm{P}$ concentration were decreased from $429300 \mathrm{~kg}$ to $43520 \mathrm{~kg}$. Figure 8 is showing the negative trend in total $\mathrm{N}$ and $\mathrm{P}$ concentration over 35 years in the study area due to huge

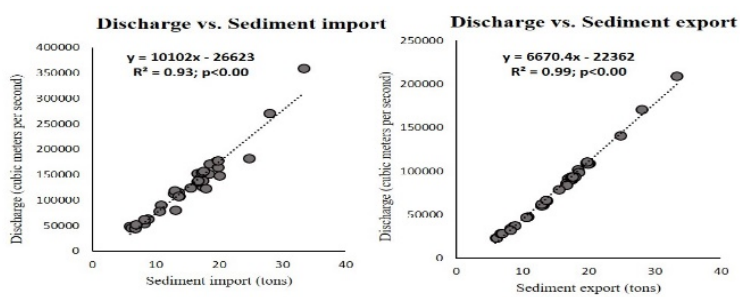

Figure 6. Relationship between river discharge and sedimentation process

sedimentation process which adversely impacted the regional agricultural yield.

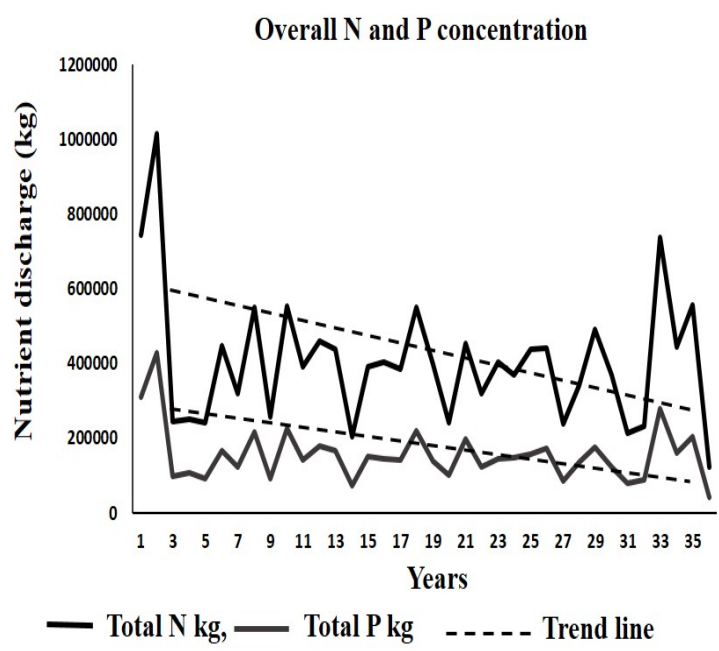

Figure 8. Total concentration of $\mathrm{N}$ and $\mathrm{P}$ over 35 years

\section{SUMMARY AND CONCLUSION}

The present study showed for the first time, that how a physical model can report and scientifically proven the serious issue of soil nutrient loss within a small catchment area over a long term period. Below mentioned summaries can address from this study:

1. Freely available EO data in association with climatic data, can work as an important input to understand the temporal variation of river discharge, sediment yield and sediment characteristics and to link their variation to catchment characteristics. Landsat 8 OLI showed its potentiality to draw the overall land use scenario of the study area whereas the accurate watershed model has successfully generated SRTM DEM. Both of these maps along with climatic datasets have proved their potentiality to estimate river discharge, sediment yield and sediment characteristics for a small scale catchment.

2. Hydrological scenario of Gandheshwari have showed that the area was hydrologically enriched with high amount of rainfall and less evapotranspiration. No such big variations were found in between maximum and minimum range of rainfall. The amount of aquifer recharge and water yield of this region were highly 
supportive for agricultural works. We expect that during normal monsoonal condition this scenario would be highly supportive towards agricultural productivity.

3. Due to suitable hydrological situation, in land use we observed that the catchment area was mostly dominated by forest and croplands. These croplands were the major support of local economy in this region.

4. It has been scientifically proved that due to rapid urbanization, land encroachment, waste disposal in rivers, the depth of Indian rivers and their capacity to flow were reduced drastically (Dutta et al., 2011). This ultimately leads to river discharge capacity which was also showed in Gandheshwari river. Due to the construction of check dams in the main stream of Gandheshwari and Dwarkeshwar river, the of amount flow discharge were regulated by the concerned authority evident from model derived stable discharge data.

5. The significant relationship with good agreement between river discharge and sediment import export rate proved that in this region sedimentation process was very active. So, the sediment import and export were highly controlled by river discharge which ultimately resulting to soil erosion in this region. This condition of sediment import and export were highly influencing the local agricultural yields and soil nutrient conditions. As our study area were experienced with flash flood situations, during that time the flow of river discharge strongly erode the soil along with its associated nutrients.

6. Gandheshwari river discharge were drastically reduced the major soil nutrients such as $\mathrm{NH}_{4}, \mathrm{NO}_{3}, \mathrm{NO}_{2}$ proved from the derived outputs. With such outcomes we can assume that nutrient biogeochemical transformation has been occurred in this region over 35 years (Moore et al., 2010). Studies showed that this biogeochemical transformation of soil have a significant influence in crop photosynthesis process, where strong decline in nutrient content in soil adversely impact to crop life (Berhe et al., 2013). Reduction in net primary productivity and input of residue to soil further affects the long-term susceptibility of the topsoil and associated $\mathrm{C}$ and $\mathrm{N}$ to loss by soil erosion (Berhe et al., 2014). So, we can assume that the deficit in $\mathrm{NH}_{4}, \mathrm{NO}_{3}, \mathrm{NO}_{2}$

\section{REFERENCES}

Bandopadhyay, S., 2016. Does elevation impact local level climate change? An analysis based on fifteen years of daily diurnal data and time series forecasts. Pacific Science Review A: Natural Science and Engineering, 18(3), 241-253.

Berhe, A. A. \& Kleber, M., 2013. Erosion, deposition, and the persistence of soil organic matter: mechanistic considerations and problems with terminology. Earth Surface Processes and Landforms. doi: 10.1002/esp.3408. concentration in soil may influence the agricultural productivity of this region.

7. Dynamic trend of $\mathrm{N}$ and $\mathrm{P}$ concentration over this area as a result of erosion processes. Specifically, erosion can result in lateral fluxes of $\mathrm{N}$ and $\mathrm{P}$ and also influence in its decrease (Quinton et al., 2010). The total concentration of $\mathrm{N}$ and $\mathrm{P}$ in soil showed a negative trend over 35 years of observation. $\mathrm{N}$ and $\mathrm{P}$ concentration in agricultural soils can significantly alter nutrient and carbon fluxes which ultimately influence to crop lifecycle. Therefore, we can state that due to the decline of $\mathrm{N}$ and $\mathrm{P}$ concentration on soil over time, it may disturb the nutrient and carbon cycling which affects the crop productivity in this region.

8. Our analysis demonstrated that why soils must be observed as dynamic systems in time and space context if we are to understand their role in major biogeochemical cycles, crop life cycles, crop productivity and agricultural yield. This study was also sought that, the fertility of the soil and its impact on crop productivity must be examined particularly for basin catchment areas from time to time.

9. It is possible to conduct this study at larger scale in various climatic scenarios along with supportive validation strategies.

10. Finally, the results indicate the efficiency of SWAT model that can be an effective tool for further analysis in different land management scenarios. This study will open new windows for small-scale observations that could help different stakeholders and farmers to plan and implement appropriate agricultural strategies at grass root level.

\section{ACKNOWLEDGEMENTS}

Special thanks to the USGS and NASA for providing freely available satellite data. The authors were also extending their thanks to anonymous reviews for their suggestions towards the enrichment of this paper. Analyses of the data were supported by the Polish National Research Centre (NCN) within the project No 2016/21/B/ST10/02271. Finally, the authors would like to thank ISPRS for considering this study into their account.

Berhe, A. A., Arnold, C., Stacy, E., Lever, R., McCorkle, E. \& Araya, S. N., 2014. Soil erosion controls on biogeochemical cycling of carbon and nitrogen. Nature Education Knowledge 5(8):2

Boesch, D. F., 2002. Challenges and opportunities for science in reducing nutrient over-enrichment of coastal ecosystems. Estuaries, 25(4), 886-900.

Dutta, V., Srivastava, R. K., Yunus, M., Pathak, S. A. V. V., Rai, A., \& Prasad, N., 2011. Restoration plan of Gomti River with designated best use classification of surface water quality based on river expedition, 
monitoring and quality assessment. Earth Science India, 4.

Hasan, M. S. U., Adhikari, K., \& Bhattacharyya, S., 2017. Morphometric Analysis using Remote Sensing and GIS. Journal of Civil Engineering and Environmental Technology. $17(22)$

Hasan, M.S.U., K. Suraj., \& Sudhanshu., 2018. Estimation of Surface runoff using geospatial model: A case study of Gandheshwari watershed, Bankura, West Bengal, India. Society for Environment and Development, (India),9 (27).

Merritt, W. S., Letcher, R. A., \& Jakeman, A. J., 2003. A review of erosion and sediment transport models. Environmental modelling \& software, 18(8-9), 761-799.

Moore, M. T., Kröger, R., Locke, M. A., Cullum, R. F., Steinriede Jr, R. W., Testa Iii, S., ... \& Cooper, C. M., 2010. Nutrient mitigation capacity in Mississippi Delta, USA drainage ditches. Environmental Pollution, 158(1), 175-184.

Neitsch SL, Arnold AG, Kiniry JR, Srinivasan JR, Williams JR., 2005. Soil and water assessment tool user's manual: version 2005. TR-192: College Station, Tex: Texas Water Resources Institute
Pal,S.C \& Debnath,G.C., 2012. "Morphometric analysis and associated land use study of a part of the Dwarkeswar watershed" International journal of geomatics and geosciences Vol. 3,pp.351-363

Quinton, J. N., Govers, G., Van Oost, K., \& Bardgett, R. D., 2010. The impact of agricultural soil erosion on biogeochemical cycling. Nature Geoscience, 3(5), 311.

Seitzinger, S. P., Harrison, J. A., Dumont, E., Beusen, A. H., \& Bouwman, A. F., 2005. Sources and delivery of carbon, nitrogen, and phosphorus to the coastal zone: An overview of Global Nutrient Export from Watersheds (NEWS) models and their application. Global Biogeochemical Cycles, 19(4).

Serur, A. B., \& AK, S., 2016. Evaluation of the ArcSWAT model in simulating catchment hydrology: in Weyib River basin, bale mountainous area of southeastern Ethiopia. Int. J, Inov. Emrg. Res. Eng, 3(2), $3-11$.

Venkatesh, B., Purandara, B. K., \& Nayak, P. C., 2018. Hydrologic Modeling, 81(August). https://doi.org/10.1007/978-981-10-5801-1

APPENDIX

\begin{tabular}{|c|c|c|c|c|c|c|c|c|}
\hline & & \multicolumn{7}{|c|}{ AVE MONTHLY BASIN VALUES } \\
\hline & & SNOW & & & WATER & & SED & \\
\hline MON & RAIN & FALL & SURF $Q$ & LAT 2 & YIELD & ET & YIELD & PET \\
\hline & (MM) & $(\mathrm{MM})$ & $(\mathrm{MM})$ & (MM) & (MM) & (MM) & $(\mathrm{T} / \mathrm{HA})$ & (MM) \\
\hline 1 & 9.71 & 0.00 & 0.35 & 0.11 & 15.42 & 14.86 & 0.05 & 133.21 \\
\hline 2 & 16.74 & 0.00 & 1.46 & 0.06 & 4.54 & 24.38 & 0.20 & 155.68 \\
\hline 3 & 13.50 & 0.00 & 1.01 & 0.05 & 3.04 & 60.47 & 0.05 & 234.02 \\
\hline 4 & 14.18 & 0.00 & 0.19 & 0.04 & 1.70 & 21.56 & 0.01 & 270.81 \\
\hline 5 & 41.62 & 0.00 & 4.69 & 0.06 & 5.50 & 28.83 & 0.15 & 282.46 \\
\hline 6 & 245.86 & 0.00 & 47.80 & 0.32 & 48.66 & 72.07 & 2.35 & 214.82 \\
\hline 7 & 503.41 & 0.00 & 151.50 & 1.31 & 187.48 & 112.77 & 8.78 & 164.38 \\
\hline 8 & 498.73 & 0.00 & 151.98 & 1.94 & 281.23 & 107.76 & 10.78 & 143.96 \\
\hline 9 & 373.95 & 0.00 & 108.49 & 1.87 & 284.72 & 91.94 & 8.71 & 127.89 \\
\hline 10 & 130.99 & 0.00 & 31.59 & 1.34 & 200.97 & 61.23 & 2.72 & 128.71 \\
\hline 11 & 18.73 & 0.00 & 4.02 & 0.59 & 107.83 & 25.91 & 0.37 & 122.53 \\
\hline 12 & 8.66 & 0.00 & 1.25 & 0.25 & 53.52 & 16.01 & 0.16 & 125.92 \\
\hline
\end{tabular}

Appendix 1. Average monthly basin values of Gandheshwari river basin. 